\title{
Determination of Cadmium in Sediments and in Sewage Sludge by Slurry Sampling Electrothermal Atomic Absorption Spectrometry Using Iridium as Permanent Modifier
}

\author{
Daniel L. G. Borges, Lúcia F. Dias ${ }^{\#}$, Márcia A. M. S. da Veiga ${ }^{\Phi}$ and \\ Adilson J. Curtius*
}

Departamento de Química, Universidade Federal de Santa Catarina, 88040-900 Florianópolis - SC, Brazil

\begin{abstract}
É proposto um procedimento para a determinação de Cd em sedimentos e em lodo de esgoto doméstico sob a forma de suspensões por espectrometria de absorção atômica com atomização eletrotérmica. As suspensões, $1 \mathrm{mg} \mathrm{mL}^{-1}$, foram preparadas pela adição de solução $5 \%$ v/v de ácido nítrico à amostra moída com tamanho de partícula $\leq 50 \mu \mathrm{m}$, em banho de ultra-som. A homogeneidade das suspensões foi assegurada pela passagem de fluxo constante de argônio no recipiente do amostrador automático, antes da transferência de alíquota da suspensão para o interior do forno de grafite. Dois modificadores permanentes depositados sobre a plataforma de grafite pirolítico foram testados: $\mathrm{Ru}$ e Ir. Modificadores em solução foram também testados: $\mathrm{Pd}+\mathrm{Mg}$ e fosfato, separadamente ou em conjunto com $\mathrm{Mg}$. O tubo tratado com Ir foi utilizado devido a sua boa performance como modificador e também por razões práticas. Cerca de $80 \%$ do Cd é extraído para a fase aquosa da suspensão. Para testar a exatidão do método, três materiais certificados foram analisados: um sedimento marinho, um sedimento fluvial e lodo de esgoto de origem doméstica. As concentrações obtidas, usando-se calibração com soluções padrão aquosas preparadas no mesmo meio das suspensões, estão em concordância com os valores certificados para intervalo de confiança de $95 \%$, após aplicação do teste Student- $t$. O limite de detecção $(3 \sigma)$ foi de $43 \mathrm{ng} \mathrm{g}^{-1}$ na amostra sólida e o desvio padrão relativo para o sedimento MESS-2 foi de 2,3\% $(n=10)$.
\end{abstract}

A procedure for the determination of $\mathrm{Cd}$ in sediment and sewage sludge as slurries by electrothermal atomic absorption spectrometry is proposed. The slurry, $1 \mathrm{mg} \mathrm{mL}^{-1}$, was prepared by mixing sample ground to a particle size $\leq 50 \mu \mathrm{m}$ with $5 \% \mathrm{v} / \mathrm{v}$ nitric acid in an ultrasonic bath. The homogeneity of the slurries was assured by passing a constant flow of argon into the autosampler cup, just before transferring an aliquot to the graphite furnace. Two permanent modifiers deposited on the platform were tested: Ru and Ir. Modifiers in solution were also tested: Pd plus Mg and phosphate alone or plus Mg. The Ir-treated tube was adopted due to its good performance as modifier and also for practical reasons. About $80 \%$ of $\mathrm{Cd}$ is extracted to the water phase of the slurry. To test the accuracy of the method, three certified materials were analyzed: a marine sediment, a river sediment and a domestic sewage sludge. The concentrations obtained, using calibration against aqueous standards prepared in the same medium as the slurries, are in agreement with the certified values, at a confidence level of $95 \%$, according to the Student $t$ test. The limit of detection $(3 \sigma)$ was $43 \mathrm{ng} \mathrm{g}^{-1}$ in the solid sample and the relative standard deviation for the sediment MESS-2 was $2.3 \%$ $(\mathrm{n}=10)$.

Keywords: cadmium, slurry, ET AAS, modifier, sediment, sewage sludge

\section{Introduction}

Cadmium is a heavy metal, relatively rare and without known vital biological functions for human beings.

*e-mail: curtius@qmc.ufsc.br

\# On leave from Centro Federal de Educação Tecnológica, Unidade Ponta Grossa, 84016-210 Ponta Grossa - PR, Brazil

${ }^{\Phi}$ Present address: Instituto de Química, Universidade de São Paulo, CP 26077, 05513-970 São Paulo - SP, Brazil
However, it is quite toxic and its concentration in the environment, even if low, requires periodic control. Cadmium contamination of the environment is due to mining, the smelter industry, discard of products that contain cadmium, such as batteries, and sewage of domestic and industrial origin. ${ }^{1} \mathrm{~A}$ critical question in agriculture is the use of sewage sludge as fertilizers due to its increasing concentrations of toxic elements. In Europe, for example, the maximum ${ }^{2,3}$ allowed $\mathrm{Cd}$ concentration in sewage 
sludge for agricultural use is $20 \mathrm{mg} \mathrm{kg}^{-1}$. Cadmium determination in sediments and in sewage sludge is becoming very important and necessary as a way to control its presence in the environment.

In general, the procedures for mineralization and dissolution of sediments and sewage are prone to sample contamination, besides being time consuming, even if assisted by microwaves. Direct solid analysis or slurry analysis are usually much faster and less subject to the risks of analyte contamination or losses. A review on direct solid, also including slurry analysis, was recently published by Kurfürst. ${ }^{4}$ The procedure to prepare a slurry is usually also very simple and the obtained sensitivity is quite high, since less sample dilution can be employed. In addition, micro-quantities of solids, such as mineral incrustations, can be analyzed., 5 The determination of heavy metals in sediments and in sewage sludge as slurries or after acid dissolution $^{3,7-10}$ and the investigation of adequate modifiers for slurries, ${ }^{2,11}$ demonstrate the continuing interest for rapid and precise methods for monitoring these metals in the environment.

The use of a chemical modifier ${ }^{12}$ facilitates the separation of the matrix from the analyte during the pyrolysis step, by forming more stable compounds or phases with the analyte and, if possible, decreasing the thermal stability of the concomitants. Cadmium is a volatile element and the use of a chemical modifier, which allows a higher pyrolysis temperature is usually important for its determination by ET AAS. The chemical modifiers more frequently used for this analyte are phosphate, magnesium nitrate and the so-called universal modifier, a mixture of palladium and magnesium nitrates. These modifiers, in solutions, are added to the sample aliquot in the graphite tube each time the sample is introduced into the tube. An alternative is to use a tube treated with one or more refractory metals, called permanent modifiers. These modifiers can be purified in situ, by applying a furnace temperature program, leading to low blank signals. ${ }^{13}$ In addition, they do not need to be pipetted into the tube each cycle, decreasing the analysis time and increasing the sample throughput. The reduced form of the platinum group metals (Pt, Ir, Ru, Rh etc.), mixed or not with another refractory metal ( $\mathrm{W}, \mathrm{Zr}$ etc.), are frequently used as permanent modifiers. ${ }^{13-15}$

In this work, a simple and fast method for the routine determination of $\mathrm{Cd}$ in sediments and in sewage sludge is reported. The performances of two permanent modifiers, Ir and $\mathrm{Ru}$, and of modifiers in solution, including a mixture of palladium and magnesium nitrates, are compared. After determining the optimized graphite furnace temperature conditions and the analyte extraction to the aqueous phase in the presence or not of hydrofluoric acid for different standing times of the slurry after its preparation, the accuracy is tested by the analysis of three certified reference materials.

\section{Experimental}

\section{Instrumentation}

A Perkin-Elmer (Norwalk, CT, USA) AAnalyst 100 atomic absorption spectrometer interfaced with a PC was used to carry out the measurements, using integrated absorbance for signal evaluation. The instrument was equipped with an HGA-800 graphite furnace and an AS72 autosampler. Unspecific light absorption was corrected by continuum light source (deuterium lamp) background correction. Argon (99.996\%, White Martins, São Paulo, Brazil) was used as purge gas. A hollow cathode lamp of $\mathrm{Cd}$, used as a specific radiation source (wavelength of 228.8 $\mathrm{nm}$ and slit width of $0.7 \mathrm{~nm}$ ), operating at $6 \mathrm{~mA}$, was from Perkin-Elmer (Part No. 3050115). Commercial pyrolytic graphite coated tubes, Part No. B0091504 with L'vov platforms, Part No. 109324 (all from Perkin-Elmer) were used as sample atomization reservoirs. Table 1 shows the optimized furnace temperature program for the $\mathrm{Cd}$ determination, using $20 \mu \mathrm{L}$ of sample slurry or of the calibration solution plus $10 \mu \mathrm{L}$ of the modifier, when applied in solution.

Table 1. Temperature program for cadmium determination in the slurries by ET AAS

\begin{tabular}{|c|c|c|c|c|c|}
\hline Step & $\begin{array}{c}\text { Temperature, } \\
{ }^{\circ} \mathrm{C}\end{array}$ & $\underset{s}{\operatorname{Ramp}}$ & $\begin{array}{l}\text { Hold, } \\
\text { s }\end{array}$ & $\begin{array}{l}\text { Flow rate, } \\
\mathrm{mL} \mathrm{min}^{-1}\end{array}$ & Read \\
\hline Drying & 90 & 10 & 15 & 250 & \\
\hline Drying & 130 & 15 & 15 & 250 & \\
\hline Pyrolysis & $700^{\mathrm{a}}$ & 1 & 30 & 250 & \\
\hline Cooling & 20 & 1 & 10 & 250 & \\
\hline Atomization & $1500^{\mathrm{a}}$ & 0 & 5 & 0 & $\mathrm{X}$ \\
\hline Cleanout & $2600^{\mathrm{b}}$ & 1 & 5 & 250 & \\
\hline
\end{tabular}

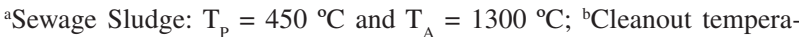
ture when permanent modifier was used: $2200{ }^{\circ} \mathrm{C}$.

\section{Reagents and samples}

Nitric acid (Carlo Erba, Milan, Italy, No. 408015) and hydrofluoric acid (Merck, Darmstadt, Germany, No. 334), used in slurry preparation, were further purified by subboiling distillation using, respectively, quartz and poly(tetrafluorethylene) sub-boiling stills, both from Kürner Analysentechnik, Rosenheim, Germany. The water was purified in a Milli-Q system (Millipore, Bedford, MA, 
USA), yielding water with a resistivity of $18 \mathrm{M} \Omega \mathrm{cm}$. The calibration solutions were prepared from dilution of a standard stock solution, $1000 \mu \mathrm{g} \mathrm{mL}^{-1}$, which was made from a high-purity, PLK20-Cd (CdO), Spex reagent (Edison, NJ, USA).

For the study of the modifiers, the following stock solutions were used: $10000 \mu \mathrm{g} \mathrm{mL}^{-1}$ of Pd (Merck No. B634689 016 ) and $10000 \mu \mathrm{g} \mathrm{mL}^{-1}$ of $\mathrm{Mg}$ (Merck No. B593213 431), both in $1 \mathrm{~mol} \mathrm{~L}^{-1} \mathrm{HNO}_{3}, 1000 \mu \mathrm{g} \mathrm{mL}^{-1}$ of Ir and $1000 \mu \mathrm{g} \mathrm{mL}^{-1}$ of $\mathrm{Ru}$, both in $1 \mathrm{~mol} \mathrm{~L}^{-1} \mathrm{HCl}$ (Fluka, Buchs, Switzerland), and $24.2 \mathrm{~g} \mathrm{~L}^{-1}$ of $\mathrm{NH}_{4} \mathrm{H}_{2} \mathrm{PO}_{4}$, prepared from proper dissolution of the solid reagent from Merck, No. 101126 . The masses of the modifiers in solution, in the $10 \mu \mathrm{L}$ volume that was pipetted into the tube, were: $15 \mu \mathrm{g}$ Pd plus $10 \mu \mathrm{g} \mathrm{Mg}, 480 \mu \mathrm{g}$ phosphate plus $20 \mu \mathrm{g} \mathrm{Mg}$ or $200 \mu \mathrm{g}$ phosphate. The surface treatments with Ru or Ir, based on a previous work, ${ }^{13}$ were carried out by pipetting $40 \mu \mathrm{L}$ of a $500 \mu \mathrm{g} \mathrm{mL}^{-1} \mathrm{Ru}$ solution or of a $500 \mu \mathrm{g} \mathrm{mL}^{-1} \mathrm{Ir}$ solution into the graphite tube, on the platform, and submitting the tube to the temperature program shown in Table 2. The entire procedure, that is, pipetting and heating, was repeated 25 times, in order to obtain a mass of permanent modifier in the tube of $500 \mu \mathrm{g}$. This temperature program also allowed the removal of contaminants from the modifiers, ensuring low blank values in the final analysis..$^{13}$ The mass of the metal deposited in the platform is quite high to assure a permanent coating, since a higher mass of the metal results in higher particle sizes and, therefore, smaller losses due to vaporization. ${ }^{16}$ An increase in tube lifetime is also frequently observed, although no further investigation was performed in this work. This procedure has been used to treat tubes in previous works, ${ }^{13,17-19}$ with excellent results.

Table 2. Temperature program for treating the graphite tube with $\mathrm{Ru}$ or Ir, as permanent modifier

\begin{tabular}{rccc}
\hline $\mathrm{T} /{ }^{\circ} \mathrm{C}$ & Ramp $/ \mathrm{s}$ & Hold $/ \mathrm{s}$ & Gas flow rate $/ \mathrm{mL} \mathrm{min}^{-1}$ \\
\hline 90 & 5 & 15 & 250 \\
120 & 15 & 10 & 250 \\
140 & 25 & 15 & 250 \\
1000 & 10 & 10 & 250 \\
2000 & 0 & 5 & 0 \\
20 & 1 & 10 & 250 \\
\hline
\end{tabular}

Three certified reference materials were analyzed: marine sediment MESS-2 (National Research Council of Canada, Ottawa, Canada), Buffalo River Sediment SRM 2704 (National Institute of Standards and Technology, NIST, Gaithersburg, MD, USA) and sewage sludge BCR 144R (Community Bureau of Reference, Brussels, Belgium).

\section{Slurry preparation}

All samples were ground in an agate mortar and passed through a $50 \mu \mathrm{m}$ polyester sieve. The slurries were prepared by mixing approximately $50 \mathrm{mg}$ of the sample with 2.5 $\mathrm{mL}$ of nitric acid and $12 \mathrm{~mL}$ of water. After leaving the slurry in an ultrasonic bath for $30 \mathrm{~min}$, the volume was made up to $50 \mathrm{~mL}$ with water. In this way, the solid concentration in the slurry was $1 \mathrm{mg} \mathrm{mL}^{-1}$ in $5 \% \mathrm{v} / \mathrm{v}$ nitric acid. The slurry was left to stand for at least $12 \mathrm{~h}$, and manually shaken just before it was poured into the autosampler cup, where it was homogenized by passing argon at a flow rate of $0.4 \mathrm{~L} \mathrm{~min}^{-1}$ through the liquid just before transferring $20 \mu \mathrm{L}$ of the slurry into the furnace.

\section{Results and Discussion}

\section{Modifiers}

The pyrolysis and atomization temperature curves for slurries of the three certified materials are shown, respectively, in Figure 1 (marine sediment), in Figure 2 (river sediment) and in Figure 3 (sewage sludge), using the two permanent modifiers and Pd plus Mg in solution. For the sewage sludge, phosphate in solution was also evaluated as modifier. The first observation is that the thermal behavior of $\mathrm{Cd}$, in the presence or not of the studied modifiers, is very dependent on the sample matrix.

For the marine sediment (Figure 1), higher pyrolysis temperatures, up to around $900{ }^{\circ} \mathrm{C}$, can be used in the presence of either the modifier in solution, $\mathrm{Pd}$ plus $\mathrm{Mg}$, or the Ir-treated tube, although the sensitivity was slightly better with the Ir-treated tube. For the river sediment (Figure 2 ), the pyrolysis curves without a modifier or in the presence of the studied modifiers, are very similar,

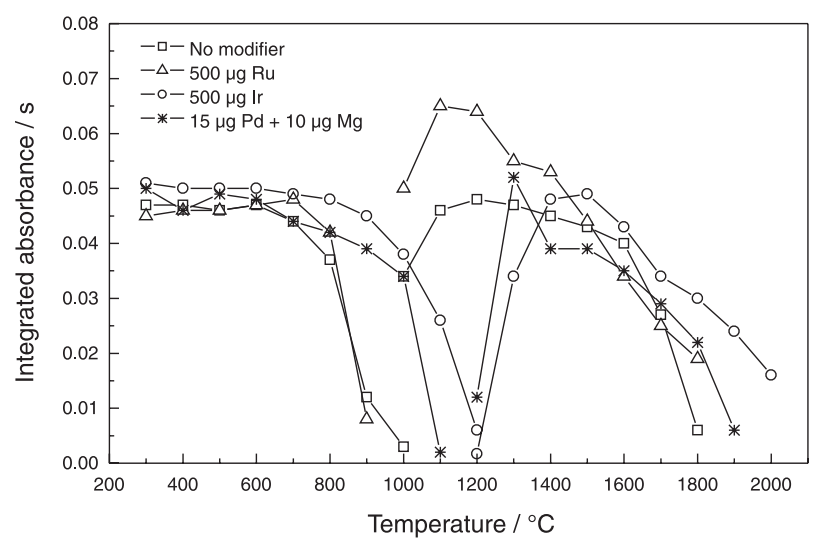

Figure 1. Pyrolysis and atomization curves for cadmium in marine sediment MESS-2 slurry ( $1 \mathrm{mg} \mathrm{mL}^{-1}$ slurry in $5 \% \mathrm{v} / \mathrm{v}$ nitric acid). Atomization temperature for the pyrolysis curves: $1500{ }^{\circ} \mathrm{C}$ and pyrolysis temperature for the atomization curves: $700{ }^{\circ} \mathrm{C}$. 


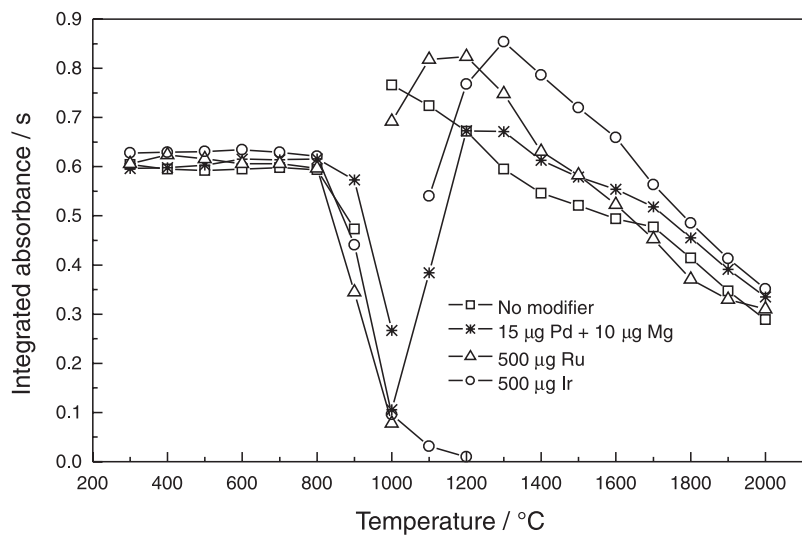

Figure 2. Pyrolysis and atomization curves for cadmium in Buffalo River Sediment SRM 2704 slurry $\left(1 \mathrm{mg} \mathrm{mL}^{-1}\right.$ slurry in 5\% v/v nitric acid). Atomization temperature for the pyrolysis curves: $1500{ }^{\circ} \mathrm{C}$ and pyrolysis temperature for the atomization curves: $700{ }^{\circ} \mathrm{C}$.

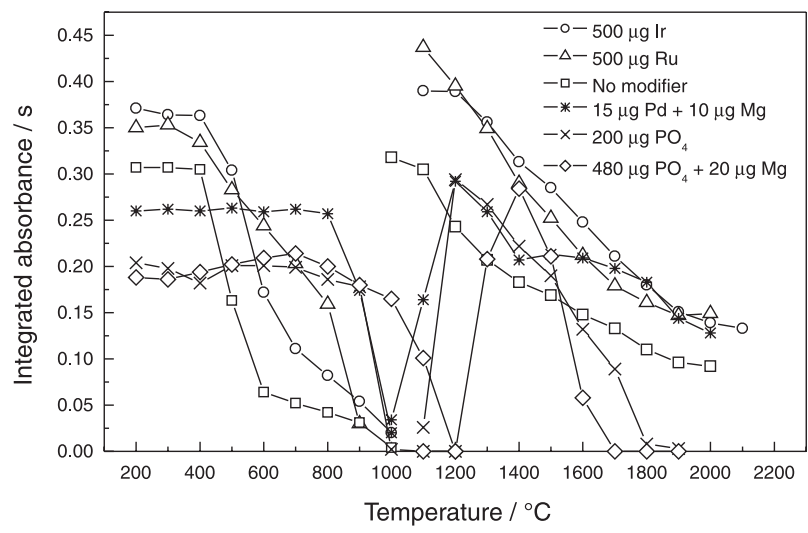

Figure 3. Pyrolysis and atomization curves for cadmium in sewage sludge BCR $144 \mathrm{R}$ slurry ( $1 \mathrm{mg} \mathrm{mL}^{-1}$ slurry in $5 \% \mathrm{v} / \mathrm{v}$ nitric acid). Atomization temperature for the pyrolysis curves: $1300{ }^{\circ} \mathrm{C}$ and pyrolysis temperature for the atomization curves: $450{ }^{\circ} \mathrm{C}$.

indicating that concomitants are acting as modifiers. The differences between the sediments of marine and river origins are evident, when Figures 1 and 2 are compared, especially when no modifier or a Ru-treated tube is used. Possibly, the chloride content in the marine sediment plays a role in these two situations, decreasing thermal stabilization. For the sewage sludge, Figure 3, the treated tubes almost did not improve the stabilization, with a maximum allowed pyrolysis temperature around $450{ }^{\circ} \mathrm{C}$, the same as when no modifier is used. The modifiers in solution, $\mathrm{Pd}$ plus $\mathrm{Mg}$, phosphate and phosphate plus $\mathrm{Mg}$ are quite effective, allowing pyrolysis temperatures up to $800{ }^{\circ} \mathrm{C}$. However, there is a loss in sensitivity for these modifiers, as demonstrated by the characteristic masses shown in Table 3.

It is also interesting to note that the maximum obtained in the atomization temperature curve for the marine
Table 3. Characteristic mass $\left(m_{0}\right)$ for cadmium, in $p g$, using different modifiers in each sample studied. The reference value, given in the software, is $0.5 \mathrm{pg} / 0.0044 \mathrm{~s}$. The pyrolysis temperature $\left(\mathrm{T}_{\mathrm{p}}\right)$ is in ${ }^{\circ} \mathrm{C}$

\begin{tabular}{lccc}
\hline Modifiers & $\begin{array}{c}\text { Sewage Sludge } \\
\mathrm{T}_{\mathrm{p}} / \mathrm{m}_{\mathrm{o}}\end{array}$ & $\begin{array}{c}\text { MESS-2 } \\
\mathrm{T}_{\mathrm{p}} / \mathrm{m}_{\mathrm{o}}\end{array}$ & $\begin{array}{c}\text { Buffalo River } \\
\mathrm{T}_{\mathrm{p}} / \mathrm{m}_{\mathrm{o}}\end{array}$ \\
\hline $\mathrm{Ir}$ & $400 / 0.4$ & $700 / 0.4$ & $800 / 0.5$ \\
$\mathrm{Ru}$ & $400 / 0.5$ & $700 / 0.4$ & $800 / 0.5$ \\
$\mathrm{No}$ modifier & $400 / 0.5$ & $600 / 0.5$ & $800 / 0.5$ \\
$\mathrm{Pd}+\mathrm{Mg}$ & $800 / 0.6$ & $600 / 0.4$ & $800 / 0.5$ \\
$\mathrm{PO}_{4}$ & $700 / 0.8$ & - & - \\
$\mathrm{PO}_{4}+\mathrm{Mg}$ & $700 / 0.8$ & - & - \\
\hline
\end{tabular}

sediment is at a lower temperature, around $1200{ }^{\circ} \mathrm{C}$, when the Ru-treated tube is used instead of the Ir-treated tube, for which the maximum is around $1500{ }^{\circ} \mathrm{C}$. The same is true for the river sediment; however the maximum for the Ir-treated tube occurs at a lower temperature, around $1300{ }^{\circ} \mathrm{C}$. For the sewage sludge slurry, a quite different behavior was observed, since the atomization temperatures at the maximum absorbance are below $1100{ }^{\circ} \mathrm{C}$, when no modifier or the treated tubes are used. When phosphate or $\mathrm{Pd}$ plus $\mathrm{Mg}$ in solution are used, the maximum is around $1200{ }^{\circ} \mathrm{C}$ and when the phosphate is mixed with $\mathrm{Mg}$, the maximum is at $1400{ }^{\circ} \mathrm{C}$.

Table 3 shows the characteristic masses obtained using the different modifiers at different pyrolysis temperatures. The characteristic mass mentioned in the software of the spectrometer is $0.5 \mathrm{pg} / 0.0044 \mathrm{~s}$. Different graphite tubes were used for the different modifiers, meaning that the data obtained are not directly comparable. However, higher sensitivities were obtained with the permanent modifiers and lower ones with phosphate, together or not with $\mathrm{Mg}$, in solution.

Since the blanks were lower with the treated tubes and since the best overall performance was achieved with the Ir-treated tube, this one was adopted in this work, using a pyrolysis temperature of $700{ }^{\circ} \mathrm{C}$ and an atomization temperature of $1500{ }^{\circ} \mathrm{C}$, except for the sewage sludge, for which the the selected pyrolysis and atomization temperatures were $450{ }^{\circ} \mathrm{C}$ and $1300{ }^{\circ} \mathrm{C}$, respectively.

\section{Extract Analysis}

The recoveries of the certified value in the aqueous phase of the MESS-2 slurry, using either $0.7 \mathrm{~mol} \mathrm{~L}^{-1}$ ( $5 \%$ $\mathrm{v} / \mathrm{v}$ ) of nitric acid or $0.7 \mathrm{~mol} \mathrm{~L}^{-1}$ nitric acid plus $0.3 \mathrm{~mol} \mathrm{~L}$ ${ }^{1}$ (or $1 \% \mathrm{v} / \mathrm{v}$ ) hydrofluoric acid, for different standing times of the slurry are shown in Figure 4. The slurries were centrifuged after a certain standing time, and the aqueous phase was analyzed by ET AAS. When only nitric acid was used, the recoveries were around $80 \%$, independent of the 


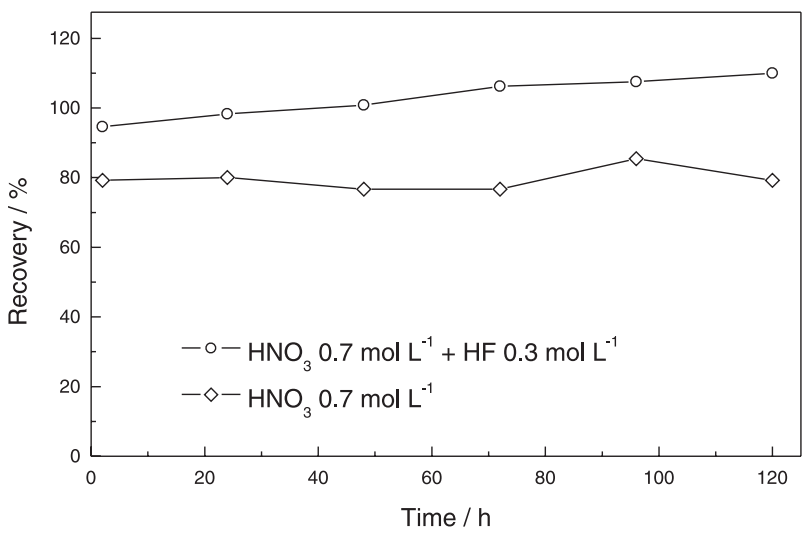

Figure 4. Influence of the standing time of the slurries (in nitric acid and in nitric acid plus hydrofluoric acid) on the recovery of the certified value for $\mathrm{Cd}$ in the aqueous phase of marine sediment MESS-2 slurries, using an Ir-treated tube.

standing time in the range studied. It is clear that the extraction was almost quantitative when the mixture of acids was used, and increased slightly with the standing time, indicating that some of the analyte is retained by the silica fraction (around 59\% w/w for MESS-2). However, in order to simplify the procedure and reduce the risks of contamination, only nitric acid was used in the further experiments. A nitric acid medium is usually chosen for determinations by ET AAS, because this acid can be easily purified by sub-boilling distillation, allows an efficient extraction of the analyte to the water phase, stabilizes the analyte in solution and leads to less interference problems. The adopted nitric acid concentration of 5\% v/v was based on a previous work. ${ }^{19}$ As will be shown, using this condition, the analytical results for the slurries were quite satisfactory.

\section{Analytical characteristics and results}

The detection limit (defined as three times the standard deviation of ten measurements of the blank divided by the slope of the calibration curve) in the solid was $43 \mathrm{ng} \mathrm{g}^{-1}$, using the Ir-treated tube. The calibration was carried out with aqueous solutions containing the same concentration of nitric acid as in the slurry. The relative standard deviation for ten measurements of the MESS-2 slurry was $2.3 \%$. The characteristic mass was already discussed.

The concentrations obtained for the three certified materials, shown in Table 4, agree very well with the certified values, according to the Student- $t$ test at a confidence level of $95 \%$, indicating absence of interferences, even using calibration against aqueous standard solutions.
Table 4. Results for cadmium in certified reference materials, prepared as $1 \mathrm{mg} \mathrm{mL}^{-1}$ slurries in $5 \% \mathrm{v} / \mathrm{v} \mathrm{HNO}_{3}$, using a Ir-treated tube as permanent modifier $(n=5)$

\begin{tabular}{lcc}
\hline Sample & Certified / $\left(\mu \mathrm{g} \mathrm{g}^{-1}\right)$ & Determined / $\left(\mu \mathrm{g} \mathrm{g}^{-1}\right)$ \\
\hline MESS-2 & $0.24 \pm 0.01$ & $0.24 \pm 0.03$ \\
SRM 2704 & $3.24 \pm 0.22$ & $3.54 \pm 0.13$ \\
BCR 144R & $1.82 \pm 0.10$ & $1.87 \pm 0.06$ \\
\hline
\end{tabular}

\section{Conclusions}

A simple, practical and efficient method is proposed for the determination of $\mathrm{Cd}$ in sediments and in sewage sludge by electrothermal atomization atomic absorption spectrometry, using Ir as a permanent modifier. The samples, after grinding to a particle size $\leq 50 \mu \mathrm{m}$, are analyzed as slurries prepared in a nitric acid solution. Calibration using aqueous solutions was effective for all the analyzed samples. About $80 \%$ of $\mathrm{Cd}$ migrates from the solid particles to the water phase of the slurry. The same method can probably be extended for the determination of other analytes in the same or in different samples.

\section{Acknowledgements}

The authors are grateful to Financiadora de Estudos e Projetos, FINEP (Project PADCT III-3-CIAMB-01/97-03/ 02-30) for financial support. A.J.C. and D.L.G.B. have fellowships from the Conselho Nacional de Desenvolvimento Científico e Tecnológico (CNPq); L.F.D. has a scholarship from the Coordenação e Aperfeiçoamento de Pessoal de Nível Superior (CAPES).

\section{References}

1. Eisler, R; Handbook of Chemical Risk Assessment - Health Hazards to Humans, Plants and Animals, Lewis Publishers: Boca Raton, 2000, vol.1.

2. Belarra, M.A.; Resano, M.; Rodríguez, S.; Urchaga, J.; Castillo, J.R.; Spectrochim. Acta Part B 1999, 54, 787.

3. Baralkiewicz, D.; Siepak, J.; Anal. Chim. Acta 2001, 437, 11.

4. Kurfürst, U. ed.; Solid Sample Analysis: Direct and Slurry Sampling using GF-AAS and ETV-ICP, Springer: Berlin, 1998.

5. Bendicho, C.; Loos-Vollebregt, M.T.C.; J. Anal. At. Spectrom. 1991, 6, 353.

6. Maia, S.M.; da Silva, J.B.B.; Curtius, A.J.; Welz, B.; J. Anal. At. Spectrom. 2000, 15, 1081.

7. López-Garcia, I.; Viñas, P.; Arroyo-Cortéz, J.; HernándezCórdoba, M.; Fresenius J. Anal. Chem. 2000, 367, 727.

8. Lima, E.C.; Barbosa, F.; Krug, F.J.; Silva, M.M.; Vale, M.G.R.; J. Anal. At. Spectrom. 2000, 15, 995. 
9. Rucandio, M.I.; Petit-Dominguez, M.D.; J. AOAC Int. 2002, $85,219$.

10. Liva, A.; Muñoz-Olivas, R.; Câmara, C.; Talanta 2000, 21, 381.

11. Rucandio, I.; Petit, D.; Fresenius J. Anal. Chem. 1999, 364, 541.

12. Welz, B.; Sperling, M.; Atomic Absorption Spectrometry, WileyVHC: Weinheim, 1999.

13. da Silva J.B.B.; da Silva, M.A.M.; Curtius, A.J.; Welz, B.; J. Anal. At. Spectrom. 1999, 14, 1737.

14. Tsalev, D.L.; D’Ulivo, A.; Lampugnani, L.; Di Marco, M.; Zamboni, R.; J. Anal. At. Spectrom. 1995, 10, 1003.

15. Volynsky, A.B.; Spectrochim. Acta Part B 1998, 53, 509.
16. Slaveykova, V.I.; Lampugnani, L.; Tsalev, D.L.; Sabbatini, L.; Spectrochim. Acta Part B 1997, 52, 2115.

17. Silva, J.B.B., Giacomelli, M.B.O., Souza, I.G., Curtius, A.J.; Microchem. J. 1998, 60, 249.

18. Aucélio, R.Q., Curtius, A.J., Welz, B; J. Anal. At. Spectrom. 2000, 15, 1389.

19. Dias, L.F., Saint'Pierre, T.D., Maia, S.M., Silva, M.A.M., Frescura, V.L.A., Welz, B., Curtius, A.J.; Spectrochim. Acta Part B 2002, 57, 2003.

Received: October 19, 2002 Published on the web: March 24, 2003 